\title{
Clinical Quality Measure Exchange is Not Easy
}

Robert L. Pbillips, Jr, MD, MSPH ${ }^{1}$

Lars Peterson, $M D, P b D^{1}$

Ted E. Palen, PhD, $M D^{2}$

Scott A. Fields, $M D, M H A^{3}$

Michael L. Parchman, MD, MPH

Jobn Johannides, PMP ${ }^{1}$

'American Board of Family Medicine, Lexington, Kentucky

${ }^{2}$ Colorado Permanente Medical Group, Institute for Health Research, Aurora, Colorado

${ }^{3} \mathrm{OCHIN}$, Portland, Oregon

${ }^{4}$ Kaiser Permanente of Washington Health Research Institute, Seattle, Washington

Conflicts of interest: authors report none.

\section{CORRESPONDING AUTHOR}

Robert L. Phillips Jr

American Board of Family Medicine 1648 McGrathiana Pkwy, Suite 550 Lexington, KY 40511

bphillips@theabfm.org

\begin{abstract}
PURPOSE The Trial of Aggregate Data Exchange for Maintenance of Certification and Raising Quality was a randomized controlled trial which first had to test whether quality reporting could be a by-product of clinical care. We report on the initial descriptive study of the capacity for and quality of exchange of wholepanel, standardized quality measures from health systems.
\end{abstract}

METHODS Family physicians were recruited from 4 health systems with mature quality measurement programs and agreed to submit standardized, physicianlevel quality measures for consenting physicians. Identified measure or transfer errors were captured and evaluated for root-cause problems.

RESULTS The health systems varied considerably by patient demographics and payer mix. From the 4 systems, 256 family physicians elected to participate. Of 19 measures negotiated for use, 5 were used by all systems. There were more than 15 types of identified errors including breaks in data delivery, changes in measures, and nonsensical measure results. Only 1 system had no identified errors.

CONCLUSIONS The secure transfer of standardized, physician-level quality measures from 4 health systems with mature measure processes proved difficult. There were many errors that required human intervention and manual repair, precluding full automation. This study reconfirms an important problem, namely, that despite widespread health information technology adoption and federal meaningful use policies, we remain far from goals to make clinical quality reporting a reliable by-product of care.

Ann Fam Med 2021;19:207-211. https://doi.org/10.1370/afm.2649.

\section{INTRODUCTION}

$\mathrm{F}$ amily physicians provide nearly $20 \%$ of all clinical outpatient visits, nearly 200 million visits in the United States annually. ${ }^{1}$ Frontline clinicians continue to report failures of certified electronic health records (EHRs) to meet federal certification requirements and to meet electronic reporting needs, the latter of which is estimated to cost them $\$ 15$ billion per year. ${ }^{2-11}$ Reducing reporting burden and enhancing the portability and utility of clinical data for quality improvement is an American Board of Family Medicine (ABFM) goal that is aligned with federal policy. ${ }^{12,13}$ In 2013, the ABFM began development of a Qualified Clinical Data Registry to assist practices whose EHRs were not serving their quality reporting needs and to reduce reporting burden. That registry, called PRIME, launched in 2016 and now actively extracts data from EHRs in more than 800 practices in 47 states (https://www. primeregistry.org).

Beyond reducing reporting burden, the ABFM aims to help practices easily access their own data for quality assessment and improvement and to reduce continuous certification burden. The ABFM recognized that many primary care physicians would not be able to connect directly to PRIME and that another passive data path was needed by which an EHR vendor, institution, or clinic system could send aggregated quality measures to the PRIME registry. ${ }^{12,14,15}$

The objective of this study was to assess whether quality measure reporting could be made a by-product of clinical care and quality 
improvement. We report here on the functional testing of quality measure exchange, that is to say, a test of the reliable exchange of whole-panel, quality measures from clinical networks. This component of the study was integral to a broader effort called the TRial of Aggregate Data Exchange for Maintenance of certification and Raising Quality (TRADEMaRQ). ${ }^{14,16,17}$ The study partners were 4 health systems with mature, established clinician quality-measurement and tracking systems. All 4 systems were willing to test ways to automate direct transmission of clinical measures.

\section{METHODS}

While TRADEMaRQ was a randomized, controlled trial, we report on the descriptive study component of the measure exchange testing experience.

\section{Recruitment}

Each of our clinical partners recruited family physicians in their networks or participating networks via face-to-face and e-mail solicitations. The ABFM provided study information in written form or via webinar, after which those physicians wanting to participate provided consent. Eligible participants were made aware that participation was voluntary and that the ABFM would not know their identity.

\section{Measures and Data Sharing}

Quality measures were calculated per each organization's protocol and uploaded to the ABFM's Secure File Transfer Protocol (SFTP) server. Measure exchange was designed to occur every 2 weeks.

Southeast Texas Medical Associates (SETMA) had an extensive history of reporting on quality metrics and publishes them, by clinician, on their website. The only additional work that was required was to format the results per the specifications of the study and to limit the results sent to family physicians participating in the study. They reported that quality control and verification of new files took approximately 4 to 6 hours and finalized files were placed into an automated job on the report server for reporting at 2-week intervals. Before each file set was submitted, they were given a brief inspection for correct formatting to make sure the data did not appear abnormal.

Kaiser Permanente Washington (KPWA) chose to report their clinical measures from their Clinical Improvement \& Prevention department's Healthcare Effectiveness Data and Information Set (HEDIS) measures, which are used both for monthly reporting and Medicare Star Rating calculations; however, KPWA outsourced these calculations to an National Committee for Quality Assurance-certified vendor who consumed KPWA data to produce annual HEDIS measures. KPWA also receives a "measure engine" from the vendor which allows KPWA to run HEDIS calculations themselves on a rolling basis.

Kaiser Permanente Colorado (KPCO) explained that although development of their reporting process was the most labor-intensive effort (350 hours), data processing and maintenance efforts (350 hours combined) were also substantial, resulting in an average 9 hours spent per data file transfer. KPCO developed a program specifically for this study to produce physician-level measures and it was run biweekly by a data specialist who also had to review and approve outputs.

OCHIN (a nonprofit health care innovation center focused on the needs of community health centers, small practices, and critical access hospitals) did not provide documentation about their process or related problems.

The study was approved by the American Academy of Family Physicians' Institutional Review Board after all parties entered into an Office for Human Research Protections-approved federal-wide authority consortium agreement.

\section{RESULTS}

\section{Enrollment and Participation}

Across the 4 networks, there were 2,570 eligible family physicians, and 256 participated (Table 1). Participation ranged from $4.4 \%$ of OCHIN physicians to $100 \%$ of eligible SETMA physicians.

\section{Data and Transfers}

The 4 partners agreed to 19 common clinical quality measures with our site co-principal investigators; across the 19 measures, however, initially only 4 were used by all health systems (Table 2) and only 5 were used by all systems by the end of the study. More than 15 examples of transmission or receipt errors were identified (Table 3). KPCO documented 17 different ways that their process was interrupted, failed, or had to be revised. Some types of errors, such as breaks in data delivery, changes in measure values, and nonsensical measure results were readily identifiable. Only SETMA had no identified errors - the only system to routinely list physician-level measures on their website for public viewing. KPWA noted 2 complications: (1) HEDIS measures change over time, both the measures required and the measure definitions; and, (2) an annual data validation process that typically delays data availability until the second quarter. Once the data were available from the vendor, KPWA wrote programs to automatically upload a physician-level measure file. KPWA staff noted, "we have internal 
Table 1. TRADEMaRQ-Enrolled Physicians

\begin{tabular}{lc}
\hline Health System & Number Enrolled \\
\hline Control & 125 \\
Kaiser Permanente Washington & 90 \\
Kaiser Permanente Colorado & 66 \\
OCHIN & 94 \\
Southeast Texas Medical Associates & 6 \\
Total & 256 \\
\hline OCHIN = a nonprofit health care innovation center focused on the needs of \\
community health centers, small practices and critical access hospitals; TRADE- \\
MaRQ = Trial of Aggregate Data Exchange for Maintenance of certification and \\
Raising Quality.
\end{tabular}

dashboards with more complete and timely data than what is reported in HEDIS, and this drives our providers absolutely crazy because the two do not agree, and we as a medical group are being judged based on HEDIS measures, not on what we know is data that better reflects our true practice of medicine and delivery of care. But no one is willing to stop producing our internal dashboards because those are used to actually implement changes that improve quality of care, not the HEDIS measures." This revelation helped explain complaints we were receiving from KPWA physicians who noted that their quality measures in their certification portfolio did not reflect their internal dashboard measures.

Table 2. TRADEMaRQ Measures across Participating Health Systems

\begin{tabular}{|c|c|c|c|c|c|c|}
\hline CMS eMeasure ID & NQF \# & Measure Title & KPWA & KРCO & OCHIN & SETMA \\
\hline CMS165v2 & 18 & Controlling High Blood Pressure & $x$ & $x$ & $x$ & $x$ \\
\hline CMS138v2 & 28 & Smoking Cessation Counseling & & $x$ & $x$ & \\
\hline CMS125v2 & 31 & Breast Cancer Screening & $x$ & $x$ & $x$ & $x$ \\
\hline CMS124v2 & 32 & Cervical Cancer Screening & $x$ & $x$ & $x$ & $x$ \\
\hline CMS130v2 & 34 & Colorectal Cancer Screening & $x$ & $x$ & $x$ & $x$ \\
\hline CMS147v2 & 41 & Preventive Care and Screening: Influenza Immunization & & & $x$ & $x$ \\
\hline CMS127v2 & 43 & Pneumonia Vaccination Status for Older Adults & & & $x$ & $x$ \\
\hline CMS131v2 & 55 & Diabetes: Eye Exam & $x$ & $x$ & $x$ & $x$ \\
\hline CMS123v2 & 56 & Diabetes: Foot Exam & & $x$ & $x$ & $x$ \\
\hline CMS122v2 & 59 & Diabetes: Hemoglobin $A_{1 c}$ Poor Control & & $x$ & $x$ & $x$ \\
\hline CMS134v2 & 62 & Diabetes: Urine Protein Screening & $x$ & & $x$ & $x$ \\
\hline CMS163v2 & 64 & Diabetes: Low Density Lipoprotein (LDL) Management & & & $x$ & $x$ \\
\hline CMS164v2 & 68 & $\begin{array}{l}\text { Ischemic Vascular Disease (IVD): Use of Aspirin or Another } \\
\text { Antithrombotic }\end{array}$ & & $x$ & $x$ & \\
\hline CMS145v2 & 70 & $\begin{array}{l}\text { Coronary Artery Disease (CAD): Beta-Blocker Therapy- } \\
\text { Prior Myocardial Infarction (MI) or Left Ventricular } \\
\text { Systolic Dysfunction (LVEF <40\%) }\end{array}$ & $x$ & & $x$ & \\
\hline CMS182v3 & 75 & $\begin{array}{l}\text { Ischemic Vascular Disease (IVD): Complete Lipid Panel } \\
\text { and LDL Control }\end{array}$ & & $x$ & $x$ & \\
\hline CMS135v2 & 81 & $\begin{array}{l}\text { Heart Failure (HF): Angiotensin-Converting Enzyme (ACE) } \\
\text { Inhibitor or Angiotensin Receptor Blocker (ARB) Therapy } \\
\text { for Left Ventricular Systolic Dysfunction (LVSD) }\end{array}$ & $x$ & $x$ & $x$ & \\
\hline CMS144v2 & 83 & $\begin{array}{l}\text { Heart Failure (HF): Beta-Blocker Therapy for Left Ventricular } \\
\text { Systolic Dysfunction (LVSD) }\end{array}$ & & & $x$ & \\
\hline CMS2v3 & 418 & $\begin{array}{l}\text { Preventive Care and Screening: Screening for Clinical Depres- } \\
\text { sion and Follow-Up Plan }\end{array}$ & & & $x$ & \\
\hline CMS68v3 & 419 & Documentation of Current Medications in the Medical Record & & & $x$ & $x$ \\
\hline
\end{tabular}




\section{DISCUSSION}

This paper reports on a test of exchange of wholepanel, standardized quality measures from clinical networks and health systems with mature internal quality measure processes, all of whom reported to HEDIS and Centers for Medicare \& Medicaid Services (CMS). Of 19 measures that the 4 agreed were common and standard, only 5 measures were used by all 4 . Dozens of identified errors or hazards in measure calculation, data management, data delivery, and physician inclusion occurred. These problems often required human intervention and manual repair, precluding fully automated file transfers. In the end, there was a steady stream of reported data and most of the enrolled physicians were able to interact with them on the secure ABFM website. We conclude that it was really a test of system-level breakdown in measure definition, process, capture, and transmission rather than about the particulars of individual clinician quality $y_{i}$ it is a symptom of the bigger system problem.

The "passive" data reporting path that TRADEMaRQ sought to test was related to the intentions of the Health Information Technology for Economic and Clinical Health Act. ${ }^{18}$ Specifically, it promoted the Office of the National Coordinator for Health Information Technology (ONC) Direct Project which aimed to create a simple, secure, scalable, standards-based way to transmit health information from a sender to a trusted recipient over the Internet. ${ }^{19}$ Direct Project priority 2 specifically mentions reporting of quality measures to a variety of potential recipients. The TRADEMaRQ aims also aligned with the ONC Nationwide Health Information Exchange intentions, namely to support secure health information exchange for measuring and improving quality tied to incentives for improvement and required reporting. ${ }^{20,21}$ This study reconfirms an important problem, namely, that despite continued growth in health information technology adoption and calls for interoperability, most clinical practices struggle to produce standard quality measures from their clinical data and to meet a growing number of reporting needs. ${ }^{22}$ Several large-scale, federal demonstration and research efforts have run headlong into this problem and are struggling to get measure data out of participating practices. ${ }^{11}$ Although many clinicians are now reporting to the federal Quality Payment Program and hardship exceptions are made for small practices, they are at increasing risk of being left behind because NCQA's patient-centered medical home recognition program is moving to annual electronic measure reporting, and many public health registries and even some payers are also requiring electronic measure submission. ${ }^{5}$ Quality reporting is unlikely to disappear but the reliability of what is reported is unclear, meaningfulness uncertain, and the cost high. ${ }^{6,7}$

\section{Table 3. Common Measure Delivery or Receipt Errors and Hazards} Experienced in TRADEMaRQ

\begin{tabular}{|c|c|c|}
\hline Error Types & Examples & Fix \\
\hline \multirow{8}{*}{$\begin{array}{l}\text { Measure } \\
\text { miscalculation }\end{array}$} & Incorrect numerator or denominator & \multirow{2}{*}{$\begin{array}{l}\text { Corrected data sent and } \\
\text { uploaded manually after } \\
\text { manual removal of incor- } \\
\text { rect data }\end{array}$} \\
\hline & $\begin{array}{l}\text { Measures calculated incorrectly sent from } \\
\text { inception, noticed } 11 \text { months after system } \\
\text { launch }\end{array}$ & \\
\hline & $\begin{array}{l}\text { Incorrect data period (measurement period } \\
\text { reguired } 12 \text { months, but } 11 \text { months used) }\end{array}$ & $\begin{array}{l}\text { Revised measure } \\
\text { calculations }\end{array}$ \\
\hline & $\begin{array}{l}\text { Incorrect denominator inclusion criteria } \\
\text { used for greater than } 1 \text { year }\end{array}$ & $\begin{array}{l}\text { Error caught internally } \\
\text { and repaired; delayed } \\
\text { transmission }\end{array}$ \\
\hline & Numerator $>$ denominator error & \multirow{4}{*}{$\begin{array}{l}\text { Fixed reporting period } \\
\text { compression error }\end{array}$} \\
\hline & Patient panel (erroneously) reduced to 0 & \\
\hline & $\begin{array}{l}\text { Physician moved clinics and changed pan- } \\
\text { els so that measures could not be recon- } \\
\text { ciled; removed from the study }\end{array}$ & \\
\hline & Significant change in scores for 5 measures & \\
\hline \multirow[t]{3}{*}{ Data delivery error } & Delay in data delivery & \multirow{3}{*}{$\begin{array}{l}\text { Corrected, resent, manual } \\
\text { data replacement }\end{array}$} \\
\hline & Blank file sent & \\
\hline & Incorrect NQF number attached to file & \\
\hline \multirow[t]{2}{*}{$\begin{array}{l}\text { Non-enrolled physi- } \\
\text { cian data sent }\end{array}$} & $\begin{array}{l}\text { Physician data sent before they were } \\
\text { enrolled/randomized }\end{array}$ & \multirow[t]{2}{*}{$\begin{array}{l}\text { Physician enrolled and ran- } \\
\text { domized or excluded }\end{array}$} \\
\hline & Ineligible physician data sent & \\
\hline \multirow[t]{4}{*}{$\begin{array}{l}\text { Data reporting } \\
\text { interrupted }\end{array}$} & $\begin{array}{l}\text { Physician data reported for one period but } \\
\text { not another }\end{array}$ & \multirow[t]{4}{*}{$\begin{array}{l}\text { Updated files sent and } \\
\text { manually uploaded }\end{array}$} \\
\hline & $\begin{array}{l}\text { Internal system change caused a measure } \\
\text { to not get reported }\end{array}$ & \\
\hline & $\begin{array}{l}\text { Source database moved and transmission } \\
\text { credentials not configured }\end{array}$ & \\
\hline & $\begin{array}{l}\text { Critical subsystem source failure, 6-week } \\
\text { delay }\end{array}$ & \\
\hline $\begin{array}{l}\text { Host receiving } \\
\text { server not running }\end{array}$ & System update interruption & Server brought back online \\
\hline \multirow[t]{2}{*}{ Third party errors } & $\begin{array}{l}\text { Two years into study, learned that a third- } \\
\text { party company was doing measure man- } \\
\text { agement and transmitting incorrectly }\end{array}$ & $\begin{array}{l}\text { Worked directly with ven- } \\
\text { dor to correct calculation } \\
\text { or transmission errors }\end{array}$ \\
\hline & $\begin{array}{l}\text { Third-party processes caused several month } \\
\text { delays in file transmission around turn of } \\
\text { calendar year }\end{array}$ & $\begin{array}{l}\text { Files caught up once data } \\
\text { sent by third party }\end{array}$ \\
\hline
\end{tabular}


A major limitation of our study is that the problems identified may not generalize to other health systems.

\section{CONCLUSION}

TRADEMaRQ and other recent studies suggest that we remain far from clinical data liquidity goals of federal agencies. The ABFM's goals to help physicians make reporting a by-product of care and ongoing quality improvement, and reduce physicians' reporting burdens, remain aspirations. While small and independent practices struggle with turning their EHR data into reportable measures, large health systems also struggle with managing measure definitions, internal vs external quality processes, and costly processes for managing reporting.

To read or post commentaries in response to this article, go to https://www.AnnFamMed.org/content/19/3/207/tab-e-letters.

Key words: health information technology; quality measures; family physicians; quality indicators; health care; certification

Submitted October 6, 2019; submitted, revised, August 13, 2020; accepted August 19, 2020.

Funding support: This project was supported by grant number R21HSO22583 from the Agency for Healthcare Research and Quality. The content is solely the responsibility of the authors and does not necessarily represent the official views of the Agency for Healthcare Research and Quality.

Acknowledgments: The authors gratefully acknowledge the assistance of Stanley Xu, PhD, Head of Biostatistics and a Senior Investigator at the Kaiser Permanente Institute for Health Research.

Supplemental materials: Available at https://www.AnnFamMed. org/content/19/3/207/suppl/DC1/

\section{References}

1. Centers for Disease Control and Prevention. NAMCS Summary Tables. Published 2012. https://www.cdc.gov/nchs/data/ahcd/ namcs_summary/2012_namcs_web_tables.pdf

2. Centers for Medicare \& Medicaid Services. Medicare program; Merit-Based Incentive Payment System (MIPS) and Alternative Payment Model (APM) incentive under the physician fee schedule, and criteria for physician-focused payment models. Fed Regist. 2016;81: 77008-77831.

3. Centers for Medicare \& Medicaid Services. Transforming clinical practice initiative. Published 2016. Accessed 2016. https://innovation.cms.gov/initiatives/Transforming-Clinical-Practices/

4. Agency for Healthcare Research and Quality. About EvidenceNOW: background and stories from the field. Published 2016. Accessed Feb 8, 2017. https://www.ahrq.gov/evidencenow/about/index.html

5. NCQA. Recognition redesign annual reporting. Published 2017. Accessed Jan 14, 2018. https://www.ncqa.org/programs/recognition/ practices/patient-centered-medical-home-pcmh/pcmh-redesign/ annual-reporting
6. Murray K, Hilligoss B, Hefner J, et al. The quality reporting reality at a large Academic Medical Center: reporting 1600 unique measures to 49 different sources. Int J Acad Med. 2017;3(1):10-15.

7. Casalino LP, Gans D, Weber R, et al. US physician practices spend more than $\$ 15.4$ billion annually to report quality measures. Health Aff (Millwood). 2016;35(3):401-406.

8. Xierali IM, Hsiao C-J, Puffer JC, et al. The rise of electronic health record adoption among family physicians. Ann Fam Med. 2013; 11(1):14-19.

9. Hsiao (-J, Decker SL, Hing E, Sisk JE. Most physicians were eligible for federal incentives in 2011, but few had EHR systems that met meaningful-use criteria. Health Aff (Millwood). 2012;31(5):1100-1107.

10. Peterson LE, Blackburn B, Ivins D, Mitchell J, Matson C, Phillips RL Jr. Do family physicians electronic health records support meaningful use? Health Care (Don Mills). 2015;3(1):38-42.

11. Cohen DJ, Dorr DA, Knierim K, et al. Primary care practices' abilities and challenges in using electronic health record data for quality improvement. Health Aff (Millwood). 2018;37(4):635-643.

12. Phillips R, Kennedy J. Jaén C, Stelter K, Puffer J. Transforming physician certification to support physician self-motivation and capacity to improve quality and safety. Journal of Enterprise Transformation. 2016;6(3-4):162-169.

13. Washington V, DeSalvo K, Mostashari F, Blumenthal D. The HITECH era and the path forward. N Engl J Med. 2017;377(10):904-906.

14. Phillips R. ABFM to simplify maintenance of certification (MOC) for family physicians and make it more meaningful: a family medicine registry. J Am Board Fam Med. 2015;28(3):431-433.

15. Cook DA, Holmboe ES, Sorensen KJ, Berger RA, Wilkinson JM. Getting maintenance of certification to work: a grounded theory study of physicians' perceptions. JAMA Intern Med. 2015;175(1):35-42.

16. DeMaio S. Simplifying MOC for famly physicians: the TRADEMaRQ study. NEJM Knowledge+. Published Mar 26, 2015. https:// knowledgeplus.nejm.org/blog/simplifying-moc-for-family-physiciansthe-trademarq-study/

17. Tachibana C. How can we streamline board certification for family physicians? Kaiser Permanente Washington. Published Feb 5, 2015. Accessed Apr 12, 2108. https://www.kpwashingtonresearch.org/ news-and-events/recent-news/news-2015/how-can-we-streamlineboard-certification-family-physicians

18. Anderson KM, Marsh CA, Flemming AC, Isenstein H, Reynolds J. Quality measurement enabled by health IT: overview, possibilities, and challenges. Published Jul 2012. Accessed Feb 9, 2013. https:// healthit.ahrq.gov/portal/server.pt/community/ahrq-funded_ projects/654/health_it-enabled_quality_measurement/30886

19. DIRECT Project Overview. Published Oct 11, 2010. Accessed Feb 9, 2013. https://www.oregon.gov/oha/HPA/OHIT-HITOC/Documents/ NHINDirectProjectOverviewWeb.pdf

20. NationaleHealthCollaborative. EXCHANGE ROADMAP: the landscape and a path forward. Published 2012. Accessed Feb 9, 2013. https://www.nationalehealth.org/hie-roadmap

21. Chassin MR, Loeb JM, Schmaltz SP, Wachter RM. Accountability measures - using measurement to promote quality improvement. N Engl J Med. 2010;363(7):683-688.

22. Krist AH, Beasley JW, Crosson JC, et al. Electronic health record functionality needed to better support primary care. J Am Med Inform Assoc. 2014;21(5):764-771. 